\title{
CONTNET OF TRACE ELEMENTS AND SOME RADIONUCLIDES IN LUCERNE (Medicago sativa)
}

\author{
M. Živkov-Baloš ${ }^{1}, \check{Z ̌}_{\text {. Mihaljev }}^{1}, \check{Z ̆}$. Ćupić $^{2}$ \\ ${ }^{1}$ Scientific Veterinary Institute "Novi Sad", Rumenački put 20, Novi Sad, Republic of Serbia \\ ${ }^{2}$ Research Institute for Reproduction, Artificial Insemination and Embryotransfer "Temerin", \\ Industrijska zona bb. 21235 Temerin, Republic of Serbia \\ Corresponding author: milica@niv.ns.ac.rs \\ Invited paper
}

Abstract: The samples of lucerne were collected from twelve different locations in Vojvodina during the summer period July- September 2004. Raw lucerne trees were cut on the height of $4-5 \mathrm{~cm}$ under the ground in the amount of $2-3 \mathrm{~kg}$. The samples were air-dried, ground, powdered and mineralized by the method of dry burning. The content of minerals, toxic elements and radionuclides in the samples of lucerne was determined. Due to low concentrations of detected toxic elements and radionuclides and contents of micro- and macro-elements, the obtained results indicate that alfalfa from the examined localities is a healthy and ecology sound feed component. However, with the aim of protecting the environment and preservation of human health, continuous surveillance of the content of toxic elements and radionuclides in lucerne, particularly in localities with increased risk of contamination, is necessary. Special attention should be given to the content and origin of mercury in soil and a possibility of contaminating plants with this toxic element. The obtained results could serve as a base for further investigations, regarding radiation-hygienic control of herbal feedstuff for animals.

pollution

Key words: alfalfa, essential elements, toxic elements, radioactive

\section{Introduction}

Being an excellent source of iron, calcium and beta-carotene lucerne is nowadays considered the most important fodder crop worldwide. Lucerne (Medicago sativa) is a perennial forage plant belonging to the pea family Leguminosae. It has a deep root system, sometimes stretching to even $4.5 \mathrm{~m}$, with the ability to fix nitrogen. Lucerne has the potential to be the most prolific of all leaf vegetable crops, processed by drying and grinding into powder, or by pulping to extract leaf concentrate. 
The food and feedstuff mainly include plants and their products; hence nutritive value of such food is highly determined by the content and ratio of the mineral matter in the plants (Živkov-Baloš et al., 1999). Having in mind that also certain toxic elements are introduced into the food chain via the plants, they may also present a source of potential contamination of the raw material used in food processing industry (Živkov-Baloš et al., 2000, 2007; Ćupić et al., 2006; Mihaljev et al. 2003; Šarić et al., 2002; Mašić et al., 2001).

The first global estimate of the fertility status and level of hazardous and harmful substances in the soils of Vojvodina was made in 1992-1993 (Kastori, 1997). This, as well as some later studies pointed out that Vojvodina could be a suitable area for the production of safe food (Mihaljev et al., 1995; Čuvardić et al., 2003).

The soil was contaminated by discharges from the Chernobyl accident in 1986 in numerous regions of Central and Eastern Europe. Radioactive elements build in plants by foil deposition and resorption through the root system. Animals and indirectly human population can be exposed to radioactivity by ingesting forage of plant origin. Radiation-hygienic monitoring requires determination of activity level for biologically significant radionuclides (BSR), which can be natural and produced. Among natural radionuclides significant is potassium-40, that in natural potassium is present with mass fraction of $0.0119 \%$ and its contribution of the total beta activity in all biological community is over $90 \%$. Among the produced radionuclides, first of all ${ }^{137} \mathrm{Cs}$ and ${ }^{90} \mathrm{Sr}$, that are, due to their physicochemical properties very toxic, and contributes radiation loading (IAEA, 1989).

Considering the constant hazard of soil contamination and accumulation of harmful elements in plants at localities close to industrial plants, the need for continuous control of harmful substances in plants presents an issue of paramount importance.

\section{Materials and Methods}

The samples of lucerne were collected from twelve different locations in Vojvodina during the summer period July - September 2004. Raw lucerne trees were cut on the height of $4-5 \mathrm{~cm}$ under the ground in the amount of 2-3 $\mathrm{kg}$. The samples were air-dried, ground, powdered and mineralized by the method of dry burning. In the air-dried samples the humidity content was determined at the temperature of $105^{\circ} \mathrm{C}$.

Determining macro- and microelements (Ca, Na, K, P, Mg, Mn, Fe, $\mathbf{Z n}, \mathbf{C u})$. Samples were air-dried, ground, powdered and mineralized by the method of dry-burning at temperature $550 \pm 10^{\circ} \mathrm{C}$. Contents of calcium, sodium and potassium was determined by the method of emission flame spectometry. The 
contents of magnesium, iron, copper, manganese, zinc and cobalt were determined by the atomic absorption spectrometry applying Varian Spectr AA-10, while phosphorus concentration was determined by spectophotometry using Spekol 221MA 9524.

Determining the lead, cadmium and arsenic contents. Samples were powdered and mineralized by the method of dry-burning at temperature $450 \pm 10^{\circ} \mathrm{C}$. Concentration of $\mathrm{Pb}$ and $\mathrm{Cd}$ was determined by using atomic absorption spectrometer Varian Spektra-10 with background corrector $\left(\mathrm{D}_{2}\right.$-lamp). The contents of As were determined using distillation procedure by the method of Kingsley-Schaffert. The developed color, the "molybdenum blue" complex, is read on an appropriate spectrophotometer at $840 \mathrm{~nm}$.

Determining the mercury content. Samples were prepared for assaying using the method of wet digestion with automatic temperature regulation (max $55^{\circ} \mathrm{C}$ ) and an aluminium thermoblock. Decomposition of samples was performed using concentrated sulphuric acid and potassium poermanganate solution. Content of $\mathrm{Hg}$ was measured using the flameless atomic absorption method, ("Cold Vapour").

Gamma-spectrometry analysis. The samples were air-dried, and then ground, powdered and mineralized by the method of dry burning at temperature of $450^{\circ} \mathrm{C} \pm 10^{\circ} \mathrm{C}$. In the air dried samples the humidity content was determined at $105^{\circ} \mathrm{C}$. Gamma spectrometry measurements of lucerne ash were performed by means of ultra low-level background germanium detector using both active and passive shielding. Time of measurement was $80 \mathrm{ks}$. Extended range $(10 \mathrm{keV}-3$ $\mathrm{MeV}$ ) GMX type HPGe detector, nominal efficiency of $32 \%$ in $12 \mathrm{~cm}$ thick cylindrical lead shield, lined with $3.5 \mathrm{~mm} \mathrm{Sn}+0.5 \mathrm{~mm} \mathrm{Cu}$ is surrounded by five 5 $\mathrm{cm} \times 50 \mathrm{~cm} \times 50 \mathrm{~cm}$ plastic veto shields. Veto plastic scintillators and Ge detector operate in anticoincidence mode, and on that way all events that are simultaneously detected in any veto and Ge detector will be rejected. The active shield reduces the integral background by factor 3 in the energy range from 50 to $2800 \mathrm{keV}$. Gamma spectrum of lucerne sample measured by active shielded HPGe detector Samples of Lucerne ash were measured in cylindrical geometry $(67 \mathrm{~mm} \times 62 \mathrm{~mm})$ with $80 \mathrm{ks}$ time of measurement. The example of gamma spectrum of lucerne sample is shown in Figure 1. The background is significantly suppressed by the developed active shielding method devices. For cesium ${ }^{137} \mathrm{Cs} 10 \mathrm{mBq} / \mathrm{kg}$ order of magnitude detection limits were achieved.

Statistical analysis. Statistical analysis of the obtained data (mean, standard deviation, variation range) was performed using the software package Statistica 7.0 


\section{Results and Discussion}

The results of measurements of macro and microelements (Table 1) indicate the variability of the content of mineral matter in lucerne samples originating from different locations, which may be due to the pedological properties of the soil and carrying out the agrotechnical measures. Higher variability was noticed for microelements, particularly iron $(20.00-271.01$ $\mathrm{mg} / \mathrm{kg}$ ). The lowest variability was observed for the contents of phosphorus, magnesium and sodium, and partly also for calcium. Samples from certain localities exhibited strong deficiency of microelement contents that could be subject of further investigation. We must emphasize that lucerne belongs to rare feedstuff with measurable cobalt concentrations, and lack of this component in a diet may cause problems, particularly in ruminants that are readily susceptible to the cobalt deficiency.

Table 1. Concentration of essential elements in lucerne samples taken from different locations in Vojvodina

\begin{tabular}{|l|c|c|c|c|c|c|c|c|c|c|}
\hline Elements & $\mathrm{Ca}$ & $\mathrm{P}$ & $\mathrm{K}$ & $\mathrm{Na}$ & $\mathrm{Mg}$ & $\mathrm{Fe}$ & $\mathrm{Cu}$ & $\mathrm{Mn}$ & $\mathrm{Zn}$ & $\mathrm{Co}$ \\
\hline & \multicolumn{9}{|c|}{$\left(\mathrm{g} \mathrm{kg}^{-1}\right)$} & \multicolumn{7}{c|}{$\left(\mathrm{mg} \mathrm{kg}^{-1}\right)$} \\
\hline Mean & 9.97 & 2.36 & 17.92 & 0.87 & 2.57 & 104.7 & 4.3 & 23.5 & 13.5 & 0.06 \\
\hline Sd & 2.05 & 0.41 & 6.58 & 0.43 & 0.64 & 103.1 & 2.8 & 12.7 & 7.5 & 0.04 \\
\hline Min & 7.83 & 1.76 & 10.01 & 0.36 & 1.84 & 20.0 & 0.1 & 0.1 & 0.08 & 0.01 \\
\hline Max & 14.03 & 3.09 & 32.69 & 2.12 & 3.74 & 271.0 & 8.3 & 46.0 & 26.3 & 0.15 \\
\hline
\end{tabular}

Results on lead, cadmium, arsenic and mercury concentration in lucerne samples originating from different localities in Vojvodina are summarized in Table 2.

Table 2. Concentration of toxic elements in lucerne samples taken from different locations in Vojvodina

\begin{tabular}{|c|c|c|c|c|}
\hline & $\mathrm{Pb}$ & $\mathrm{Cd}$ & As & $\mathrm{Hg}$ \\
\hline \multicolumn{5}{|c|}{$\left(\mu \mathrm{g} \mathrm{kg}^{-1}\right)$} \\
\hline Mean & 509 & 33.8 & 220 & 127.1 \\
\hline $\mathrm{Sd}$ & 301 & 11.1 & 85 & 120.0 \\
\hline Min & 200 & 20.0 & 141 & 20.0 \\
\hline Max & 1130 & 60.0 & 442 & 370.7 \\
\hline
\end{tabular}


As obvious from the displayed data, the content of lead in the analyzed lucerne samples is not significant $(200-1130 \mu \mathrm{g} / \mathrm{kg})$ ranging within the maximum allowed concentration. The same applies to arsenic content, which ranged from 141 to $442 \mu \mathrm{g} / \mathrm{kg}$. The cadmium concentrations measured in the investigated samples ranged within an interval of $20.0-60.0 \mu \mathrm{g} / \mathrm{kg}$. The results given in Table 2 indicate that the concentrations of selected toxic elements $(\mathrm{Pb}, \mathrm{Cd}$ and $\mathrm{As})$ are lower than the maximum allowed concentrations (Pravilnik, 2010). Our analysis revealed that the contents of $\mathrm{Hg}$ in alfalfa samples from some of the locations were higher than maximum allowed concentration. The cause of this phenomenon still remains to be elucidated (Čuvardić et al., 2006).

Results of gamma spectrometry analysis of lucerne samples are shown in Table 3. Activity concentrations of radionuclides: ${ }^{134} \mathrm{Cs},{ }^{137} \mathrm{Cs},{ }_{137}^{226},{ }^{232} \mathrm{Th}$ and ${ }^{40} \mathrm{~K}$ were expressed in units of $\mathrm{mBq} / \mathrm{kg}$. In some of samples cesium ${ }^{137} \mathrm{Cs}$ was detected in traces. These concentrations are 200 times lower as compared with the results obtained in 1988, two years after Chernobyl accident (Bikit et al., 1990), when the average ${ }^{137}$ Cs activity concentration was $(9.0 \pm 1.0) \mathrm{Bq} / \mathrm{kg}$. The sophisticated sample preparation and counting techniques enabled the detection of ${ }_{40}^{226} \mathrm{Ra}$ and ${ }^{232} \mathrm{Th}$ in almost all samples. The dominant ${ }^{40} \mathrm{~K}$ activity concentration is expected for plants (Forkapić et al., 2006).

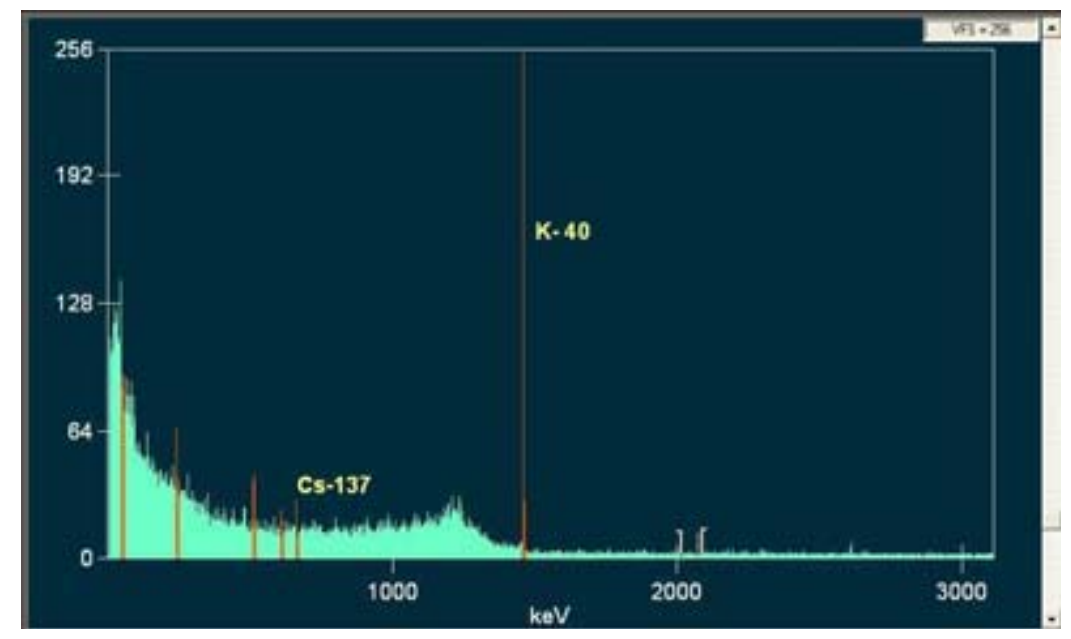

Figure 1. Gamma spectrum of Lucerne sample measured by active shielded HPGe detector 
Table 3. Activity concentrations of ${ }^{134} \mathrm{Cs},{ }^{137} \mathrm{Cs},{ }^{226} \mathrm{Ra},{ }^{232} \mathrm{Th}$ and ${ }^{40} \mathrm{~K}$ in lucerne samples taken from different locations in Vojvodina

\begin{tabular}{|c|c|c|c|c|c|}
\hline Isotope & ${ }^{\mathbf{1 3 4}} \mathbf{C s}$ & ${ }^{\mathbf{1 3 7}} \mathbf{C s}$ & ${ }^{\mathbf{2 2 6}} \mathbf{R a}$ & ${ }^{\mathbf{2 3 2}} \mathbf{T h}$ & ${ }^{\mathbf{4 0}} \mathbf{K}$ \\
\hline Location & \multicolumn{5}{|c|}{$\mathrm{A}[\mathrm{mBq} / \mathrm{kg}$ fresh mass $]$} \\
\hline 1 & $<75$ & $122 \pm 22$ & $175 \pm 100$ & $90 \pm 62$ & $(121 \pm 4) \times 10^{3}$ \\
\hline 2 & $<100$ & $<100$ & $302 \pm 70$ & $218 \pm 25$ & $(140 \pm 4) \times 10^{3}$ \\
\hline 3 & $<80$ & $70 \pm 15$ & $<300$ & $80 \pm 15$ & $(92 \pm 3) \times 10^{3}$ \\
\hline 4 & $<75$ & $<100$ & $<150$ & $<38$ & $(103 \pm 3) \times 10^{3}$ \\
\hline 5 & $<100$ & $<100$ & $<1500$ & $112 \pm 28$ & $(141 \pm 4) \times 10^{3}$ \\
\hline 6 & $<100$ & $<125$ & $275 \pm 225$ & $132 \pm 30$ & $(191 \pm 6) \times 10^{3}$ \\
\hline 7 & $<75$ & $<75$ & $450 \pm 150$ & $335 \pm 22$ & $(88 \pm 3) \times 10^{3}$ \\
\hline 8 & $<75$ & $<100$ & $175 \pm 150$ & $65 \pm 20$ & $(144 \pm 5) \times 10^{3}$ \\
\hline 9 & $<125$ & $<150$ & $198 \pm 53$ & $125 \pm 75$ & $(272 \pm 8) \times 10^{3}$ \\
\hline 10 & $<68$ & $<75$ & $200 \pm 150$ & $75 \pm 58$ & $(133 \pm 4) \times 10^{3}$ \\
\hline 11 & $<125$ & $<150$ & $<375$ & $188 \pm 55$ & $(158 \pm 7) \times 10^{3}$ \\
\hline 12 & $<1125$ & $125 \pm 32$ & $<350$ & $105 \pm 38$ & $(115 \pm 6) \times 10^{3}$ \\
\hline
\end{tabular}

Obvious variations in potassium content lead to the conclusion that incorporation of radionuclides from the soil into the plants largely depend on pedological properties, soil exploitation and agrotechnical treatments. It is known that phosphoric manure contains significant quantities of heavy elements products of uranium decay and so contributes the increase of environment radioactivity (Ćupić et al., 2005).

\section{Conclusion}

Due to low concentrations of detected toxic elements and radionuclides and contents of micro- and macro-elements, the obtained results indicate that alfalfa from the examined localities is a healthy and ecology sound feed component. However, with the aim of protecting the environment and preservation of human health, continuous surveillance of the content of toxic elements and radionuclides in lucerne, particularly in localities with increased risk of contamination, is necessary. Special attention should be given to the content and origin of mercury in soil and a possibility of contaminating plants with this toxic element. The obtained results could serve as a base for further investigations, regarding radiation-hygienic control of herbal feedstuff for animals. 


\title{
Acknowledgment
}

Research was financed by the Ministry of Education and Science, Republic of Serbia, project TR 31084.

\section{Sadržaj minerala, toksičnih elemenata i radionuklida u uzorcima lucerke (Medicago sativa)}

\author{
M. Živkov-Baloš, Ž. Mihaljev, Ž. Ćupić
}

\section{Rezime}

Uzorci lucerke sakupljeni su sa 12 lokacija u Vojvodini, tokom perioda julseptembar 2004. godine. Stabljike lucerke sečene su na visinu od 4-5 cm iznad površine tla, u količini od 2-3 kg uzorka. Uzorci su prirodno sušeni, mleveni i mineralizovani metodom suvog spaljivanja. U uzorcima je određen sadržaj minerala, toksičnih elemenata i radionuklida. $\mathrm{Na}$ osnovu niskih koncentracija toksičnih elemenata i radionuklida, a povoljnog sadržaja makro i mikroelemenata može se zaključiti da je lucerka sa ispitivanih lokaliteta zdravo i ekološki bezbedno hranivo. U cilju zaštite okoline i zdravlja ljudi i životinja, neophodan je monitoring prisustva toksičnih elemenata i radionuklida, posebno na lokacijama sa povećanim rizikom zagađenja. Posebnu pažnju treba posvetiti istpitivanjima sadržaja i porekla žive u zemljištu i mogućnostima kontaminacije biljaka ovim elementom.

\section{References}

BIKIT I., SLIVKA J., VESKOVIĆ M., ČONKIĆ LJ., KRMAR M., MIHALJEV Ž. (1990): Contamination of soil and food with radionuclides from Chernobyl, Proc. of the Int. Symp. on Post-Chernobyl Environmental Radioactivity Studies in East European Countries, Kazimierz -1990, edited by P. Stergnar et al., Maria Curie-Sklodowska University, Lublin, Poland, 34-37.

ĆUPIĆ Ž., MIHALJEV Ž., KLJAJIĆ R., ŽIVKOV-BALOŠ M., IVANČEV A. (2005): Total beta activity, Potassium-40 activity and residual beta activity in Alfalfa samples in Vojvodina region. XI International Feed Technology Simposium, "Quality assurance", Faculty of Technology - Novi Sad, Feed Technology Department, Vrnjačka Banja, 229-232.

ČUPIĆ Ž., MIHALJEV Ž., VESELINOVIĆ S., ČUPIĆ S., ŽIVKOV-BALOŠ M., IVANČEV A. (2006): Sadržaj molibdena u hrani za životinje. Biotehnologija u stočarstvu, 22, 575-581.

ČUVARDIĆ M., HADŽIĆ V., SEKULIĆ P., KASTORI R., BELIĆ M., GOVEDARICA M., NEŠIĆ LJ., PUCAREVIĆ M., VASIN J. (2003): Quality 
control of agricultural soils and irrigation water in Vojvodina province. Periodical of Scientific Research on Field and Vegetable Crops, Novi Sad, 40, 115-127.

ČUVARDIĆ M., SEKULIĆ P., MIHALJEV Ž., ŽIVKOV-BALOŠ M., ĆUPIĆ Ž. (2006): Essential and toxic elements in solis, feed and food in Vojvodina province. Proceedings of International Symposium on Trace elements in the Food Chain, Budapest, May 25-27, 220-224.

FORKAPIĆ S., BIKIT I., MRĐA A., VESKOVIĆ M., MIHALJEV Ž., ĆUPIĆ Ž. (2006): Low-level gamma spectroscopy measurements of radium and cesium in lucerne (Medicago sativa). Book of Abstracts, $6^{\text {th }}$ International Conference of the Balkan Physical Union, Istanbul, Turkey, 386.

IAEA (1989): Measurement of Radionuclides in Food and the Environment, Vienna.

KASTORI R. (1997): Heavy metals in the environment. Research Institute of Field and Vegetable Crops, Novi Sad.

MAŠIĆ Z., KLJAJIĆ R., MIHALJEV Ž., ŽIVKOV-BALOŠ M., ĐILAS S. (2001): Teški metali u životnoj sredini kao faktor poremećaja zdravlja životinja. Zbornik radova i kratkih sadržaja, '13.Savetovanje veterinara Srbije', Zlatibor 11.14.09.2001, Beograd, Srpsko veterinarsko društvo.

MIHALJEV Ž., KLJAJIĆ R., ŽIVKOV M., PAVKOV S. (1995): Ukupna beta aktivnost i aktivnost stroncijuma-90 u nekim sirovinama za industrijska hraniva. Zbornik radova I EKO-KONFERENCIJA 1995, Novi Sad, 265-268.

MIHALJEV Ž., ŽIVKOV-BALOŠ M., RATAJAC R. (2003): Rasprostranjenost žive u različitim uzorcima iz životne sredine. Zaštita životne sredine gradova i prigradskih naselja, Međunarodna Eko-konferencija 2003, 24-27 septembar, Novi Sad, Novi Sad, Ekološki pokret grada Novog Sada, 483-488.

PRAVILNK O KVALITETU HRANE ZA ŽIVOTINJE (2010): Službeni glasnik Republike Srbije, broj 4, član 99.

ŠARIĆ M., PSODOROV Đ., ŽIVKOV-BALOŠ M., MIHALJEV Ž. (2002): Tehnološki i zdravstveno bezbedni kvalitet pšenice u zavisnosti od rejona proizvodnje. Žito hleb, 29, 5-6, 205-212.

ŽIVKOV-BALOŠ M., MIHALJEV Ž., ĆUPIĆ Ž., VUKAŠINOVIĆ M., VIDIĆ B. (2007): Toxic elements ih feed and raw materials produced in Vojvodina. Zbornik radova - Proceedings of I International congress «Food technology, quality and safety», Novi Sad, 13-15.11, 2007, Institut za prehrambene tehnologije u Novom Sadu, 353-358 (srp), 348-353(eng).

ŽIVKOV-BALOS M., MIHALJEV Ž., MAŠIĆ Z. (1999): Količine makro i mikroelemenata u hranivima sa područja Vojvodine. Savremena poljoprivreda, 47, $1-2,285-288$.

ŽIVKOV-BALOŠ M., ŠARIĆ M., MIHALJEV Ž., ĐILAS S. (2000): Nivoi toksičnih elemenata i ostalih mineralnih materija u pšenici. Zdrastveno bezbedna hrana, Eko-konferencija 2000, 27.-30. septembar, Novi Sad, Ekološki pokret Grada Novog Sada, 267-272. 